\title{
PEMBERIAN PAKAN PELET DAN CACING SUTERA PADA PEMELIHARAAN BENIH IKAN HIAS NEMO
}

\section{FEEDING CLOWNFISH WITH PELLET AND SILKWORM ON CLOWNFISH SEED CONSERVATION}

\author{
Rahmi $^{1 *}$, Ramses ${ }^{1}$ dan Pramuanggit P. ${ }^{2}$ \\ ${ }^{1}$ Program Studi Pendidikan Biologi, Fakultas Keguruan dan Ilmu Pendidikan \\ Universitas Riau Kepulauan. Batam- Indonesia \\ ${ }^{2}$ Balai Perikanan Budidaya Laut (BPBL), Batam- Indonesia \\ *Koresponden: rahmikumbang@gmail.com
}

\begin{abstract}
Abstrak
Kegiatan ini dilaksanakan pada tanggal 01 September - 30 November 2016 yang bertempat di Bagian Ikan Hias dan Kekerangan Balai Perikanan Budidaya Laut Batam, Kota Batam - Kepulauan Riau. Benih ikan hias Nemo dipelihara dalam wadah aquarium dengan volume 25 liter sebanyak 3 buah. Selama pemeliharaan benih ikan Nemo diberikan pakan pelet pada aquarium A, pakan mix : pellet dan cacing sutera pada aquarium B dan pemberian cacing sutera $100 \%$ pada aquarium C. Pemberian pakan dilakukan 3 kali sehari yaitu pagi, siang dan sore. Pakan diberikan hingga ikan kenyang. Benih ikan hias nemo dipelihara selama kurang lebih dua bulan. Sebagai hasil diharapkan akan diperoleh data berupa pertumbuhan serta kualitas air selama kegiatan. Hasil penelitian menunjukkan bahwa setelah 40 hari pemeliharaan dan 5 kali sampling didapatkan pertumbuhan berat mutlak paling besar adalah aquarium A yaitu 0,472 gram sedangkan aquarium $\mathrm{C}$ tidak dapat dihitung karena berat akhir ikan lebih ringan dari pada berat awal, hal ini selaras dengan SGR (pertumbuhan harian) aquarium A paling cepat pertumbuhannya yaitu 0,012 gram per hari sedangkan aquarium $\mathrm{C}$ tidak dapat dihitung. Untuk pertambahan panjang mutlak ikan nemo pada aquarium A paling panjang yaitu $0,82 \mathrm{~cm}$ dan yang paling rendah yaitu aquarium $\mathrm{B}$ dengan panjang $0,66 \mathrm{~cm}$.
\end{abstract}

Kata Kunci : Cacing sutra, ikan Nemo, pertumbuhan, pakan

\begin{abstract}
This activity was held on September 1st, - November 30th, 2016 located in Batam marine ornamental and shell Conservation. Batam - University of Kepulauan Riau. Clownfish seeds were preserved in 3 aquariums with 25 liters in volume. During the converstaion, Clownfish seeds in aquarium A were fed on pellet, aquarium B were fed on pellets and silk worms mix and $100 \%$ silk worm was given in aquarium C. Feeding time was done 3 times a day; morning, afternoon and afternoon. Fishes were fed full. Clownfish seeds preserved for approximately two months. Expected result data wwere growthness and water quality information during the activity. The results showed that after 40 days of preservation and 5 times of sampling, the highest absolute weight gained was in aquarium A; 0.472 gram, meanwhile the in $C$ aquarium cold not be calculated because the final weight of the fish was lighter than the beginning weight, it was similar to SGR (daily growth) in aquarium A, it was fastest in growth of 0.012 grams per day meanwhile in aquarium $C$ could not be calculated. For length growthness of Clownfish, longest aquarium is $0.82 \mathrm{~cm}$ and the lowest was in the aquarium $B$ with the length $0.66 \mathrm{~cm}$.
\end{abstract}

Keywords: Silkworm, Clownfish, growth, feed 


\section{PENDAHULUAN}

Ikan hias merupakan salah satu komoditas perikanan yang menjadi komoditas perdagangan yang potensial di dalam maupun di luar negeri. Ikan hias dapat dijadikan sebagai sumber pendapatan devisa bagi negara. Ikan hias memiliki daya tarik tersendiri untuk menarik minat para pecinta ikan hias (hobiis) dan juga kini banyak para pengusaha ikan konsumsi yang beralih pada usaha ikan hias. Kelebihan dari usaha ikan hias adalah dapat diusahakan dalam skala besar maupun kecil ataupun skala rumah tangga, selain itu perputaran modal pada usaha ini relatif cepat (Sihombing, et all., 2013).

Budidaya ikan hias laut telah berkembang secara pesat terutama pada teknologi pembenihan dan pembesaran beberapa jenis ikan hias laut. Sentra-sentra budidaya ikan hias laut telah berkembang di Lampung, Lombok, Ambon, dan Bali. Peningkatan ini banyak disebabkan oleh kebutuhan ekspor ikan hias laut.

Salah satu jenis ikan hias laut yang diminati oleh pasar luar negri adalah ikan nemo/badut/clownfish (Amphiprion sp). Ikan ini memiliki keunggulan yaitu memiliki beberapa variasi bentuk dan warna yang beragam berdasarkan perbedaan jenis di habitatnya. Parameter keindahan jenis ikan hias dapat diukur dari bentuk badan, fisik, warna, dan tingkah lakunya. Ikan hias sangat unggul pada kecerahan warna tubuhnya, yang disebabkan adanya sel pigmen atau khromatofor yang terdapat dalam dermis pada sisik ikan (Rohmawaty 2010 dalam Oktaviani, et all., 2015. Penambahan astaxanthin memberikan pengaruh terhadap peningkatan warna dan sintasan tetapi tidak berpengaruh terhadap pertumbuhan (Yulianti, et all., 2014). Ikan Nemo merupakan ikan omnivore (pemakan hewan dan tumbuhan). Selain invertebrate kecil seperti crustacea dan parasit yang melekat pada tubuh anemon, alga juga diketahui memenuhi 20 - 25\% kebutuhan nutrisinya (Fahmawati, 2014).

Clownfish merupakan salah satu jenis produk ikan hias air laut yang paling banyak diminati terutama di pasar luar negeri karena bentuknya yang eksotis dan unik. Saat ini produksi ikan hias nemo secara budidaya sudah mulai digalakkan, namun produksi belum kontinue saat dibutuhkan untuk ekspor dan harga alam lebih murah dari harga ikan nemo produksi hatchery karena tingginya paktor produksi.

Cacing sutera Tubifex sp. merupakan pakan alami yang bagus untuk ikan hias. Di dalam tubuh cacing sutera terkandung protein sekitar 57\% dan lemak sebanyak 13\%. Inilah mengapa cacing sutra merupakan pakan alami bibit ikan yang bergizi tinggi. Sangat cocok untuk mempercepat pertumbuhan larva berbagai jenis ikan. Cacing sutera berguna untuk 
memunculkan pigmen warna serta mencerahkan warna ikan hias, seperti ikan koi. Ukuran cacing sutra terbilang kecil seperti rambut berwarna merah dengan panjang tubuh sekitar 1 - 3 $\mathrm{cm}$ dan beruas-ruas. Sangat disukai oleh bibit ikan karena tubuhnya bergerak-gerak sehingga memancing larva untuk memakannya. Kandungan gizi yaitu protein 57\% dan lemak $13 \%$ membuat cacing sutra berguna untuk mempercepat pertumbuhan larva ikan.

Berdasarkan hal tersebut diatas, maka perlu dilakukan perekayasaan pemberian pakan cacing sutera pada pemeliharaan benih ikan hias Nemo untuk memperoleh pertumbuhan ikan nemo yang berkualitas.

\section{METODOLOGI PENELITIAN}

\section{Waktu dan Tempat}

Kegiatan ini dilaksanakan pada tanggal 01 September - 30 November 2016 yang bertempat di Bagian Ikan Hias dan Kekerangan Balai Perikanan Budidaya Laut Batam, Kepulauan Riau

\section{Alat dan Bahan}

Peralatan dan bahan yang digunakan dalam penelitian ini adalah sebagai berikut: Peralatan terdiri dari alat kualitas air (DO Meter, refraktometer dan thermometer) aquarium, seperangkat alat sampling (penggaris, timbangan dan alat tulis) ember, serokan, aerator dan saringan. Sedangkan bahan yang digunakan adalah benih Ikan hias nemo, cacing sutera dan pelet komersial

\section{Metode Kerja}

Mekanisme/cara kerja yang digunakan adalah kegiatan ini diawali dengan pemeliharaan benih ikan hias Nemo dalam wadah aquarium dengan volume 25 liter sebanyak 3 buah dengan masing-masing aquarium diisi 20 ekor ikan hias Nemo. Selama pemeliharaan benih ikan Nemo diberikan pakan pelet pada aquarium A, pakan mix pellet dan cacing sutera pada aquarium B dan pemberian cacing sutera $100 \%$ pada aquarium C. Pemberian pakan dilakukan 3 kali sehari yaitu pagi, siang dan sore. Pakan diberikan hingga ikan kenyang. Benih ikan hias nemo dipelihara selama kurang lebih dua bulan. Sebagai hasil diharapkan akan diperoleh data berupa pertumbuhan serta kualitas air selama kegiatan. 
Tabel 1. Jadwal pemberian pakan benih ikan hias nemo

\begin{tabular}{cccc}
\hline $\begin{array}{c}\text { Jadwal } \\
\text { pemberian pakan }\end{array}$ & Aquarium A & Aquarium B & Aquarium C \\
\hline Pagi & Pelet & Pelet & Cacing Sutera \\
\hline Siang & Pelet & Cacing Sutera & Cacing Sutera \\
\hline Sore & Pelet & Cacing Sutera & Cacing Sutera \\
\hline
\end{tabular}

Pengamatan yang dilakukan terhadap beberapa parameter pertumbuhan ikan yaitu pertambahan berat dan panjang tubuh ikan yang berkaitan erat dengan kegiatan perekayasaan ini. Sampling pertumbuhan dilakukan dengan cara mengukur panjang dan berat semua ikan Nemo yang digunakan untuk kegiatan ini.

\section{Pertumbuhan}

Secara sederhana, pertumbuhan diartikan sebagai perubahan ukuran, dapat panjang atau berat dalam waktu tertentu. Dengan demikian untuk menghitung pertumbuhan ini diperlukan data panjang atau berat dan umur atau waktu (Effendi, 1979). Pertumbuhan ini secara fisik diekspresikan dengan perubahan jumlah atau ukuran sel penyusun jaringan tubuh dalam rentang waktu tertentu. Sedangkan secara morfologi, pertumbuhan diwujudkan dalam bentuk (metamorfosis). Sementara secara energetik, pertumbuhan dapat diekspresikan dengan perubahan kandungan total energi (Kalori) tubuh pada periode tertentu. Pertumbuhan dipengaruhi dua faktor, yaitu faktor internal, diantaranya, sifat keturunan, seks, dan umur, sedangkan faktor eksternal antara lain, linkungan perairan, pakan, dan penyakit. Dalam mengamati dan menghitung pertumbuhan dikenal dengan pertumbuhan mutlak dan pertumbuhan harian.

Laju pertumbuhan harian yang merupakan prosentase dari selisih bobot akhir dan bobot awal yang dibagi dengan lamanya waktu pemeliharaan dihitung menggunakan rumus :

$\mathrm{SGR}=\frac{W t-W o}{T}$

Dimana,

SGR = Laju pertumbuhan $(\mathrm{g})$

Wo = Bobot hewan uji pada awal pemeliharaan $(\mathrm{g})$

$\mathrm{Wt}=$ Bobot hewan uji pada akhir pemeliharaan $(\mathrm{g})$

$\mathrm{T}=$ Waktu pemeliharaan (hari) 
Pertumbuhan mutlak diukur secara periodik dari awal hingga akhir penelitian selama dua bulan dengan menimbang bobot biomassa benih nemo, pertumbuhan mutlak dapat dihitung dengan rumus (Effendi, 1979) :

$\mathrm{W}=\mathrm{Wt}-\mathrm{Wo}_{\mathrm{o}}$

Dimana,

W : Pertambahan bobot mutlak (g)

Wo : Bobot hewan uji pada awal penelitian $(\mathrm{g})$

Wt : Bobot hewan uji pada akhir penelitian $(\mathrm{g})$

Panjang mutlak diukur secara periodik dari awal hingga akhir penelitian selama dua bulan dengan mengukur panjang benih ikan nemo, panjang mutlak dapat dihitung dengan rumus (Effendi, 1979) :

$\mathrm{L}=\mathrm{Lt}-\mathrm{Lo}$

Dimana,

L : Pertambahan panjang mutlak (cm)

Lo : Panjang hewan uji pada awal penelitian $(\mathrm{cm})$

Lt : Panjang hewan uji pada akhir penelitian $(\mathrm{cm})$

\section{HASIL DAN PEMBAHASAN}

\section{Pengukuran Kualitas Air}

Pada pengecekan kualitas air harian pada pemeliharaan benih ikan hias nemo dapat dilihat bahwa kualitas air media pemeliharaan tidak terlalu mengalami fluktuasi dan masih sangat layak untuk media pemeliharaan sesuai dengan baku mutu menurut Madhu et al. 2011.

Tabel 2. Pengukuran parameter kualitas air

\begin{tabular}{|c|c|c|c|c|c|c|c|c|}
\hline \multirow[b]{2}{*}{ No } & \multirow{2}{*}{$\begin{array}{c}\text { Parameter } \\
\text { Kualitas Air }\end{array}$} & \multirow{2}{*}{$\begin{array}{l}\text { Baku } \\
\text { Mutu }\end{array}$} & \multirow{2}{*}{ Satuan } & \multicolumn{5}{|c|}{ Sampling } \\
\hline & & & & I & II & III & IV & $\mathbf{V}$ \\
\hline 1. & Salinitas & $30-34$ & $\%$ & 31 & 31 & 31 & 30 & 31 \\
\hline 2. & Oksigen terlarut & $4-8$ & $\mathrm{mg} / \mathrm{L}$ & 6,91 & 5,12 & 5,65 & 6,21 & 6,31 \\
\hline 3. & Temperatur & $28-32$ & ${ }^{0} \mathrm{c}$ & 29,3 & 29,8 & 30 & 29,8 & 30 \\
\hline
\end{tabular}

Pada operasi pengujian kualitas air dilakukan lima kali pengecekan air. Hasil yang didapat untuk pengecekan salinitas didapatk rentang pengukuran antara 30 - 31 ppt, keadaan ini dianggap normal karena standar baku untuk salinitas air laut berkisar 30 - 34 ppt. Menurut Boyd (1982) salinitas untuk air laut berkisar 30 - 40 ppt. Untuk pengukuran oksigen terlarut didapatkan rentang pengukuran antara 5, 12 - 6,91 mg/l, keadaan ini dalam kisaran normal 
karena minimal untuk hidup, biota laut membutuhkan oksigen terlarut diatas 5,00 mg/l. Untuk pengukuran suhu air didapat rentang suhu antara $29,3-30^{\circ} \mathrm{C}$, keadaan ini masih didalam baku mutu untuk pengukuran suhu yaitu rentang $28-32^{0} \mathrm{C}$. Dari ketiga aspek pengukuran kualitas air diatas, media air yang digunakan memenuhi standar untuk kehidupan ikan yang normal sehingga tidak mengganggu hasil.

Tabel 3. Pertumbuhan Panjang (cm) dan Berat (gr) Benih Ikan Hias Nemo

\begin{tabular}{rlrlrlrl}
\hline \multirow{2}{*}{ No } & \multirow{2}{*}{ Sampling } & \multicolumn{2}{c}{ Pelet } & \multicolumn{2}{c}{ Mix } & \multicolumn{2}{c}{ Cacing Sutera } \\
\cline { 3 - 8 } & & Pj & Bt & Pj & Bt & Pj & Bt \\
\hline 1 & Sampling I & 4,06 & 1,74 & 4,06 & 1,74 & 4,06 & 1,74 \\
2 & Sampling II & 4,22 & 1,98 & 4,16 & 1,814 & 4,1 & 1,416 \\
3 & Sampling III & 4,64 & 2 & 4,54 & 1,9 & 4,16 & 1,634 \\
4 & Sampling IV & 4,78 & 2,038 & 4,62 & 1,998 & 4,64 & 1,568 \\
5 & Sampling V & 4,88 & 2,212 & 4,72 & 2,04 & 4,75 & 1,608 \\
\hline
\end{tabular}

$\mathrm{Pj}=$ Panjang; $\mathrm{Bt}=$ Berat

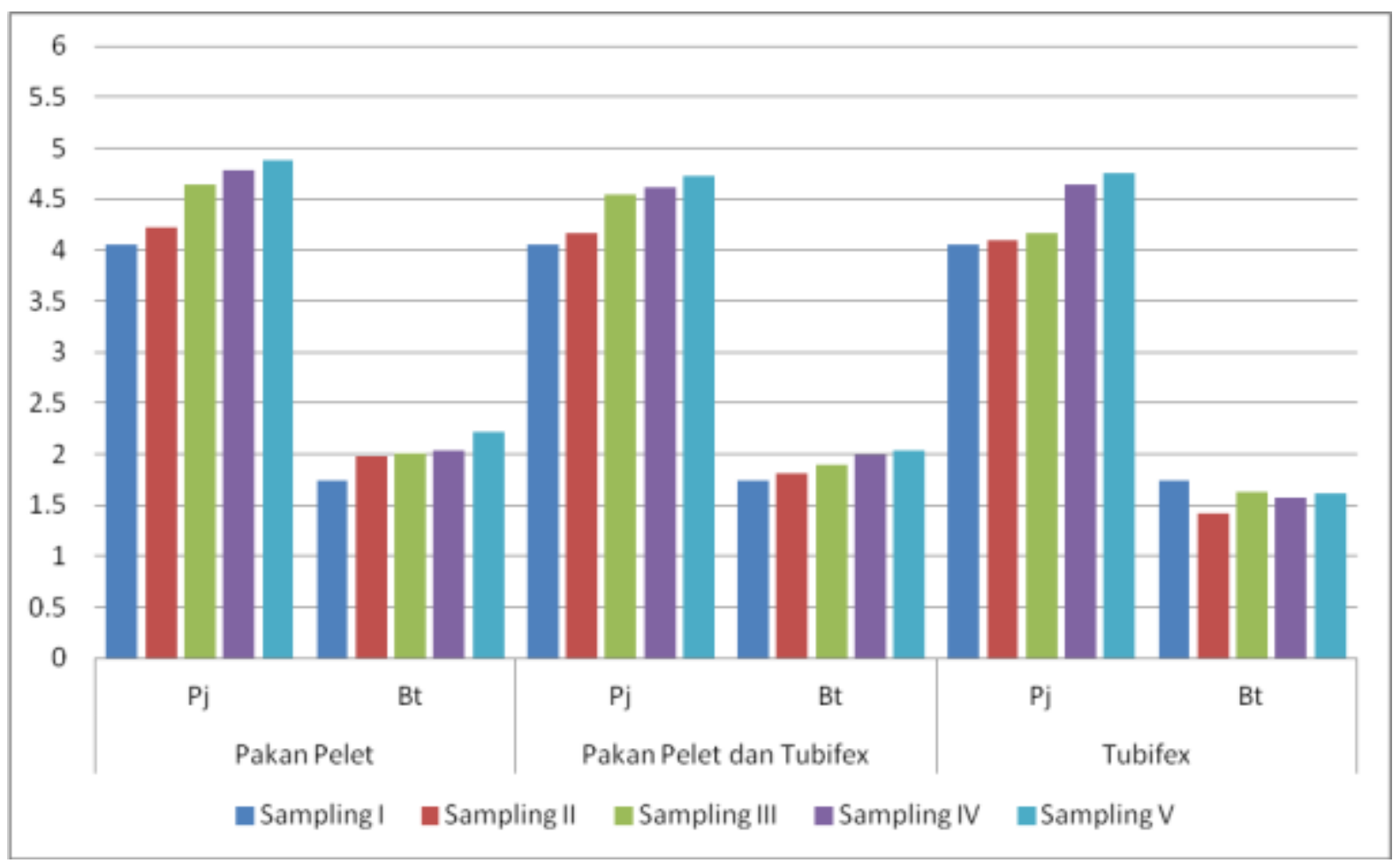

Gambar 1. Pertumbuhan Panjang (Pj) dan Berat (Bt) Ikan Nemo pada masing-masing perlakuan 
Tabel 4. Penghitungan Pertumbuhan Benih Ikan Nemo

\begin{tabular}{clccc}
\hline No & \multicolumn{1}{c}{ Sampling } & Pelet & Mix & Cacing Sutera \\
\hline 1 & SGR (gram) & 0,012 & 0,008 & $\#$ \\
2 & Berat Mutlak (gram) & 0,472 & 0,300 & $\#$ \\
3 & Panjang Mutlak (cm) & 0,82 & 0,66 & 0,69 \\
\hline \multicolumn{2}{r}{$\#$ = tidak dapat dihitung (nilai sangat kecil) } & &
\end{tabular}

\section{Pertumbuhan}

Ikan Badut dibagi kedalam tiga aquarium dengan kepadatan 20 ekor peraquarium. Aquarium A diberi pakan pellet murni, aquarium B diberikan pakan mix yaitu campuran antara pellet dan cacing sutera sedangkan aquarium C diberi cacing sutera 100\%. Setelah 40 hari pemeliharaan dan 5 kali sampling didapatkan data bahwa pertumbuhan berat mutlak paling besar adalah aquarium A yaitu 0,472 gram sedangkan aquarium $\mathrm{C}$ tidak dapat dihitung karena berat akhir ikan lebih ringan dari pada berat awal, hal ini selaras dengan SGR (pertumbuhan harian) aquarium A paling cepat pertumbuhannya yaitu 0,012 gram per hari sedangkan aquarium $\mathrm{C}$ tidak dapat dihitung.

Untuk pertambahan panjang mutlak ikan nemo pada aquarium A paling panjang yaitu $0,82 \mathrm{~cm}$ dan yang paling rendah yaitu aquarium $\mathrm{B}$ dengan panjang 0,66 cm. Aquarium $\mathrm{C}$ tidak bisa diukur pertumbuhan mutlak dan pertumbuhan harian karena berat akhir ikan mengalami penurunan dari pada berat awal sebelum perlakuan. Meskipun ikan Nemo merupaka ikan omnivore (pemakan hewan dan tumbuhan). Jadi, selain invertebrate kecil (crustacea dan parasit yang melekat pada tubuh anemon), alga juga diketahui memenuhi 20 25\% kebutuhan nutrisinya (Fahmawati, 2014). Pemberian cacing sutra ternyata belum bisa menggantikan $80 \%$ kebutuhan pakan hewaninya. Kemungkinan masih diperlukan adaptasi untuk memberikan pakan cacing sutra sebagai pengganti crustacea dan parasit kecil sebagai sumber pakan hewani untuk ikan Nemo.

\section{KESIMPULAN}

Dapat disimpulkan bahwa pada benih ikan hias nemo pemberian pakan paling bagus adalah dengan pellet pabrik. Pemberian dengan cacing sutra 100\% tidak bagus terhadap pertumbuhan. Hal ini dimungkinkan karena pemberian cacing sutra ternyata belum bisa menggantikan $80 \%$ kebutuhan pakan hewaninya. Kemungkinan masih diperlukan adaptasi untuk memberikan pakan cacing sutra sebagai pengganti crustacea dan parasit kecil sebagai 
sumber pakan hewani untuk ikan Nemo. Untuk itu diperlukan perekayasaan yang lebih detail dan berkelanjutan untuk menemukan pakan alternative yang bagus untuk pertumbuhan ikan hias Nemo.

\section{REFERENSI}

Boyd, C.E., 1982. Water Quality Management for Pond Fish Culture. Elsevier Scientif Publishing Company, New York, USA.

Effendie, M.I. 1997. Biologi Perikanan. Yayasan Pustaka Nusatama. Yogyakarta. 163 hal

Fahmawati. Y. 2014. 20 Jenis Budidaya Laut. Mitra Edukasi Indonesia. Bandung Hlm 21.

Madhu.K., Madhu. R. 2011. Breeding and Rearing Teachniques For Protandric Tropical Clownfish Amphiprion percula Under Captive Condition. Journal of Aquacultur in the Tropis.

Oktaviani, Iskandar, dan Lili W. 2015. Efektivitas Penambahan Ekstrak Buah Pepaya Pada Pakan Terhadap Peningkatan Kecerahan Ikan Badut (Amphiprion ocellaris). Jurnal Perikanan Kelautan Vol. VI No. 2 (1):125-129.

Sihombing. F., Artini. N. W., Dewi. R. K. 2013. Kontribusi Pendapatan Nelayan Ikan Hias Terhadap Pendapatan Total Rumah Tangga di Desa Serangan. E-jurnal Agribisnis dan Agrowisata. Vol 2. No. 4.

Yulianti, E. S., Maharani, H. W. dan Diantari, R. 2014. Efektivitas Pemberian Astaxanthin Pada Peningkatan Kecerahan Warna Ikan Badut (Amphiprion ocellaris). Rekayasa dan Teknologi Budidaya Perairan. Volume III No (1): 313-318. 